\title{
IAMJ
}

INTERNATIONAL

AYURVEDIC

MEDICAL JOURNAL

ISSN: 23205091

Impact Factor: 5.344

\section{MANAGEMENT OF ARDITA THROUGH PANCHAKARMA AND PALLATIVE CARE - A CASE STUDY}

\author{
Aabha Sharma ${ }^{1}$, Zenica D' Souza ${ }^{2}$ \\ ${ }^{1}$ PG Scholar, Department of Kayachikitsa, AAMCH, Moodbidri, D.K., Karnataka, India \\ ${ }^{2} \mathrm{MD}$ (Ayu), Phd, Professor and HOD Department of Kayachikitsa, AAMCH, Moodbidri, D.K., Karnataka, India \\ Corresponding Author: aabhashar543@gmail.com
}

https://doi.org/10.46607/iamj4408092020

(Published online: September 2020)

Open Access

(C) International Ayurvedic Medical Journal, India 2020

Article Received: 31/08/2020 - Peer Reviewed: 08/09/2020 - Accepted for Publication: 08/09/2020

D) Check for updates

\section{ABSTRACT}

Ardita is a condition that develops due to excessive aggravation of Vata and causes distortion of face, considered as one among the eighty Vata Nanatmaja Vyadhi in Ayurveda. Bell's palsy, the paralysis of facial nerve also affects the movement of facial muscles and shows similar symptoms, hence, can be correlated with the disease. A 39 years old Hindu male patient approached to Kayachikitsa OPD (Out Patient Department) who was suffering from complaints of deviation of lips towards right side, difficulty in closure of eyes and speech x 20 days. He was clinically diagnosed as Ardita (Bell's palsy) and managed through Panchakarama \& Palliative treatment. The patient got complete relief in all symptoms with appreciable changes.

Aim: to manage the Ardita through Panchakarma and Palliative treatment.

Methodology: In the present study both Panchakarma and Palliative management were selected for the management of Ardita in 39 years old married male patient for 7 days and follow up treatment was also recommended. Results: The patient improved on $8^{\text {th }}$ day as the symptoms were almost recovered.

Conclusion: Ardita can be managed by giving comprehensive management of Panchakarma and palliative treatment which reflects that it is good remedy for this Vata Vyadhi.

Keywords: Ardita, Bell's Palsy. 


\section{INTRODUCTION}

Shabdakalpadruma indicates Ardita as a condition where a person is afflicted, a specific disease that afflicts the Urdhavanga (Jatrordhava- parts above the neck, particularly face). It is derived from the root word "Ardana" which means pain or discomfort or trouble. According to Amarakosha it (ardita) means hurting or torturing ${ }^{[1]}$. It is considered as one among the eighty Vata Nanatmaja Vyadhi in our Ayurvedic classics $^{[2] .}$ It is also considered a "Shiro Roga" since Shiras is the Adhishthana in this entity. Charaka Acharya opines that this disease is localized in half of the face with or without the involvement of the body [3]. While Sushruta has considered as the face is only affected in Ardita. He further added that auxiliary points that, following Rakta Kshaya, (depletion of blood) in specific group of patients get afflicted by Ardita $^{[4]}$. Ardita is also explained as Ekayaam by Ashtang Hrudaya ${ }^{\{5\}}$. Acharya Arunadutta has clarified that Ardita is the disease of the body mostly affecting half of the face ${ }^{[6]}$, same quoted by the Sharangadhara ${ }^{[7]}$ due to excessive aggravation of Vata and causes distortion of face. It is considered under Asthi-Majjagata Vata in Bhela Samhita ${ }^{[8]}$. It can be correlated with the disease 'Bell's palsy in modern aspects. It is a condition that developed, facial palsy, the paralysis of facial nerve, also affects the movement of facial muscles and shows similar symptoms due to inflammation of the facial nerve within its canal above the Stylomastoid foramen.

\section{Case Report}

Type of Study: A case report (Interventional study)

Study Details: A 39 years old Hindu married male patient (labour) from Borgudde, Karnataka came to Kayachikitsa OPD (Out Patient Department) of our college (AAMCH, Moodbidri) - OP No. $-8225 / 19$

Chief Complaints: - Deviation of lips towards right side - Difficulty in closure of eyes and speech x 20 days

History of present illness: Patient was normal, gradually he developed fever (Feb 2019), After few days he experienced eruptions on tongue with burning sensation, earache along with the fever on $5 / 2 / 19$, Herpes- Zoster was diagnosed on $7 / 2 / 19$, patient observed deviation of lips and face towards right side. Gradually he also found difficulty in closure of left eye and difficulty in speech.

Past History: nothing contributory

Family History: nothing contributory

Treatment History: Patient was prescribed the following medicines by a Neuro-physician before approaching to our hospital.

On 5/2/19 $\rightarrow$ Wysolone (20mg), Acivir (800mg), Cap. Surbex XT (0-1-0), Ciplox (eye ointment)

Personal history: Appetite - Good; Bowel - One time/day; Micturation - 6-7 times/day; Sleep - Disturbed; Diet - Mixed; Addiction - Chewing Tobacco x 5 yrs.

General physical examination: Pulse - 76/min.; B.P. - 130/86 mmHg; R.R. - 20/min.; Pallor - Absent; Oedema - Absent; Clubbing - Absent; Cynosis - Absent; Icterus - Absent; Lymphadenopathy - Absent, Gait - Free swing; Speech - Slurred

Ashta sthana pareeksha: Nadi - Vatapittaja; MalaPrakruta; Mootra - Prakruta; Jihva - Vaikruta (alipta); Shabda - Prakruta; Sparsha - Prakruta; DrikVaikruta; Aakruti - Vaikruta mukha Prakruta - deha

Dashavidha pareeksha: Prakruti - Vatapittaj; Vikruti - Ardita; Sara - Madhyama; Samhanana - Madhyama; Pramana - Madhyama; Aahara shakti Madhyama; Vyayama shakti- Madhyama; Vaya Madhyama; Satva-Madhyama; Satmya-Madhyama Nidana panchaka:

Hetu-Utpadaka Hetu - Nidanaarthakara roga Visarpa (Sankramika hetu)- Vyanjaka hetu - laborious work, Poorvaroopa - Jwara, daha, Roopa - Difficulty in closure of eyes and speech Deviation of lips towards right side Upashayal Anupashaya - nothing specific observed.

\section{Central Nervous System Examination:}

- Higher Motor Functions - intact

- Consciousness - Conscious

- Orientation to - Time, place, person - Intact

- Memory - Recent - not affected, Remote - not affected

- Intelligence - Intact

- Hallucination \& Delusion - Absent 
- Speech - Slow and words are mumbled

\section{Cranial Nerve Examination:}

\begin{tabular}{|c|c|c|c|}
\hline Sr. no. & Cranial nerve & Function & Features in patient \\
\hline 1 & I (olfactory) & Smelling & smell sensation normal. \\
\hline 2 & II (optic) & & Visual acuity - Intact, Visual field - Intact \\
\hline 3 & III (oculomotor) & Eyeball \& eyelid & Doll's eye movements; movement on left side Present $\rightarrow$ Ptosis \\
\hline 4 & IV (trochlear) & Eye position \& movements & - \\
\hline 5 & $\mathrm{~V}($ trigeminal $)$ & Facial sensation & $\begin{array}{l}\text { Sensation \& mastication intact. } \\
\text { Herpes zoster - reactivation of latent herpes can affect any dorsal } \\
\text { sensory root ganglion. }\end{array}$ \\
\hline 7 & VII(facial) & $\begin{array}{l}\text { Facial expression \& taste } \\
\text { sensation }\end{array}$ & $\begin{array}{l}\text { Raising of eyebrows obliterated Towards }\left(2 / 3^{\text {rd }} \text { of tongue }\right) \underline{\text { left side. }} \\
\text { blowing of mouth-air flows out through left side. } \\
\text { angle of mouth deviated towards right side. } \\
\text { hypersensitivity on right side of tongue. }\end{array}$ \\
\hline 8 & VIII(vestibule) & Hearing \& balance & Intact, well balanced \\
\hline 11 & XI(accessory) & Trapezius, SCM & Free neck movements \\
\hline 12 & XII(hypoglossal) & $\begin{array}{l}\text { Tongue movement \& ap- } \\
\text { pearance }\end{array}$ & Mildly altered \\
\hline
\end{tabular}

\section{Vyavachedaka nidana:}

- Ardita (Charaka okta, Sushruta okta) Charaka Acharya opines that this disease is localized in half of the face with or without the involvement of the body. According to Acharya Sushruta, the Vata vitiated gets localised in the half of the face (mouth and other regions of the head), Lower motor neuron lesion facial palsy, Upper motor neuron lesion facial palsy

- Ramsay hunt syndrome- occurs in HERPES ZOSTER infection of facial ganglion, produces severe LMN Facial Palsy, buccal ulceration, ipsilateral loss of taste and painful vesicular eruptions in ext. auditory meatus.

Diagnosis: Ardita (Facial/ Bell's palsy); Post Herpes facial palsy (Ramsay hunt syndrome)

\section{Chikitsa sootra}

Ardite Navanm Moordhanitailam Tarpanameva Cha I Nadisveda Upanaha Cha Anoopapishite Hita II ch.chi.28/100 II

Treatment: Pachakarma/ shodhana chikitsa: Marsha nasya KBT $101 \times 7$ days, Ksheera dhooma $x 7$ days, Shamana chikitsa: On 28/2/19 Kamadugha rasa (moutika) 1-1-1- Dhanadanyanadi kshaya 15 ml, BD,
- Abhraka bhasma (4gm), Pravala pishti (5gm) 1/2 tsf, Guduchi satwa (20gm) tds, Ashwagandha churna (20gm), - Soota shekhara rasa (2-0-2) $x$ for $3 w k s$ were prescribed., On second follow up 24/3/19 Ksheera dhooma, -Marsha nasya KBT $101 \times 7$ days, Kamadugha rasa (1-1-1) were advised, Third follow up 31/3/19 Cap Vatapy (1-0-1) - Mahavidhwansaka rasa (1-1-1), - Ksheerabala 101 - Dhanadanyanadi Kashaya 15ml, BD x 7 days were given. Fourth follow up 6/5/19 Anu tail (Pratimarsha Nasya) 4 drops $x$ BD, - Mahavatavidhwansa (1-1-1), - Cap Palsineuron (1-0-1) x 1 month., Last follow up i.e. on 6/6/19 same treatment to be continued $\mathrm{x} 1$ month has been advised as the treatment were showing good improvement in the symptoms.

Result: The patient was evaluated and treated according to Ayurvedic principles. From the case study we can conclude that Ardita can be successfully managed by Ayurvedic treatment with lesser chance of recurrence and without any side effects. Ptosis and palate movements were cured completely. Facial expression and tongue sensation were still present mildly. 


\section{DISCUSSION}

Facial paralysis (lower motor neuron-LMN) can be considered as one of the conditions in Ardita, as it is a disease of broad spectrum. Sushruta acharya's description about Ardita holds more apt while we corelate it with the condition of facial palsy, Whereas Charaka acharya and Vagbhata considered the involvement of the body also in Ardita. Bell's palsy is the common type of LMN facial nerve paralysis. The various manifestations of facial nerve lesions at different sites has been mentioned as lakshanas of Ardita clearly by our Acharyas years back. Charaka attributed the root cause of Ardita to highly vitiated Vata dosha whereas Shodhal classified it on doshic influence of Kapha and Pitta rather than Vata. Nadi sweda (tubal sudation) and Nasya (errhine therapy) is explained in classics like Charaka and Sushruta for the treatment of Ardita. As per Vagabhata and Charaka, Ardita requires a nourishing type of therapy ${ }^{9]}$.

Keeping all these efficacious treatments in mind, the comprehensive treatment was planned. Mrudu sweda before Nasaya (oil used pacifies Vata - relieves its obstruction. Nourishes nervous system by neural, diffusion and vascular pathway ${ }^{10}$ ) and after facial massage leads to the dilatation of local blood vessels, enhances local circulation and increases the blood flow to the peripheral arterioles, stimulates the local nerves too that accelerates the drug absorption and fast improvement of the diseased ${ }^{[11]}$.

\section{CONCLUSION}

Ardita (Bell's palsy) can be managed with comprehensive application of Sweda, Ksheer Dhooma, Nasya and palliative treatment such as Cap. Palsineuron, Dhanadanyanadi Kashaya, Cap. Ksheerbala 101, Mahavatavidhwansa. Combined treatments pacify the vitiated Vata in the body and provide nourishment to the sense organs. Moreover, the drugs used internally and externally are having additional effect in relieving all the signs and symptoms. However, as this is a single case study, similar studies needed to be done on larger sample size to establish statistical significance of present line of treatment.

\section{REFERENCES}

1. Amarakosha Sanskrit English dictionary, 3/1/97.

2. Yadavji Trikamji Acharya, Chakrapani Dutta, Ayurveda Deepika Charaka Samhita Sutra, 17/12, 1st ed, 2000, Choukumbha Surabharati Prakashan, Varanasi, p.p 99.

3. Yadavji Trikamji Acharya, Chakrapani Dutta, Ayurveda Deepika Charaka Samhita Chikitsa, 28/42, 1st ed, 2000, Choukumbha Surabharati Prakashan, Varanasi, pp 618.

4. Yadavji Trikamji Acharya, Sushruta Samhita, Nidana1/69, 4th edition, Choukhamba Orientalia, Varanasi, 1980, pp 267.

5. K.R. Shastri Navre, Astanga Hridaya Nidana, 15/34, edited by Hari Sadashiva Shastri Paradakara, Choukumbha Surabharati Prakashan, Varanasi, 2002, pp 533.

6. Sadashiva Shastri Paradkar, Arunadatta, Sarvangasundari, Astanga Hridaya, Nidana, 15/36, 1st ed, 2002, Choukumbha Surabharati Prakashan, Varanasi, pp 533

7. Sailaja srivatsava, Sharangadhara Samhita, Poorvakhanda, 7/106, 2nd ed, 1998, Choukumbha Orientalia, Varanasi, pp 91.

8. Girirajadayal Shukla, Bhela Samhita Chikitsa, 24/4499, 1st ed, 1959, Choukumbha Vidyabhavan, Varanasi.

9. Sharma Ram Karan \& Dash Bhaagvan, Charaka Samhita, Vol.5, Chikitsa sthana, Chaukhambha Sanskrit Series, Varanasi. Reprint edition, 2004, p.31.

10. Tripathi Ravi Dutta, Astangsangrah, Sutrasthana 31/3, Chaukhambha Sanskrita Pratisthana, Varanasi. Reprint 2005, p. 529.

11. Shastri Pt.Kashinath and Chaturvedi Gorakhnath, Charaka Samhita, Sutrasthana, 14/2024, Chaukhambha Bharti Academy, Varanasi. Reprint 2008, p. 286.

\section{Source of Support: Nil \\ Conflict of Interest: None Declared}

How to cite this URL: Aabha Sharma \& Zenica D' Souza: Management Of Ardita Through Panchakarma And Pallative Care - A Case Study. International Ayurvedic Medical Journal \{online\} 2020 \{cited September, 2020\} Available from: http://www.iamj.in/posts/images/upload/4565 4568.pdf 